\title{
Essay
}

\section{Educational Challenges of Molecular Life Science: Characteristics and Implications for Education and Research}

\author{
Lena A.E. Tibell* and Carl-Johan Rundgren ${ }^{\dagger}$
}

*Visual Learning and Communication, Department of Science and Technology, ITN, and ${ }^{\dagger}$ Department of Thematic Studies-Water and Environmental Studies, Linköping University, 60174 Norrköping, Sweden

Submitted September 11, 2008; Revised October 29, 2009; Accepted November 4, 2009

Monitoring Editor: Erin Dolan

\begin{abstract}
Molecular life science is one of the fastest-growing fields of scientific and technical innovation, and biotechnology has profound effects on many aspects of daily life-often with deep, ethical dimensions. At the same time, the content is inherently complex, highly abstract, and deeply rooted in diverse disciplines ranging from "pure sciences," such as math, chemistry, and physics, through "applied sciences," such as medicine and agriculture, to subjects that are traditionally within the remit of humanities, notably philosophy and ethics. Together, these features pose diverse, important, and exciting challenges for tomorrow's teachers and educational establishments. With backgrounds in molecular life science research and secondary life science teaching, we (Tibell and Rundgren, respectively) bring different experiences, perspectives, concerns, and awareness of these issues. Taking the nature of the discipline as a starting point, we highlight important facets of molecular life science that are both characteristic of the domain and challenging for learning and education. Of these challenges, we focus most detail on content, reasoning difficulties, and communication issues. We also discuss implications for education research and teaching in the molecular life sciences.
\end{abstract}

\section{INTRODUCTION}

Our understanding of how living systems work at a molecular level has grown enormously during the past 50 years. Major influences include the "omic" (metabolomic, proteomic, and genomic) and biotechnological breakthroughs as well as the application of a wide array of information and methodologies from diverse scientific disciplines. This science is often referred to as "molecular life science."

The rapid progress and potential applications of molecular life science have profound implications, not only on our scientific understanding, but also on our future health and prosperity. Our daily lives have already been affected by the development of new drugs, medical diagnostics, and treatments, and the impact of molecular life science will continue to expand in the future. In addition, the ethical issues raised by its applications, for example, in food production, genetic profiling, and forensic techniques, are complex and of in-

DOI: $10.1187 /$ cbe.08-09-0055

Address correspondence to: Lena A.E. Tibell (lenti@itn.liu.se). creasing importance. Ethical implications (Maddox, 1998), taken together with the complex nature of the content, pose distinct challenges for education that have to be met by new strategies and fundamental reappraisals of our practices at all levels of life science education.

The rapid growth and the inter- and multidisciplinarity of molecular life science place demand on the selection of content. In fact, there is a large gap between what is known by practicing molecular life scientists and what is taught about the domain in secondary schools and universities (Howitt et al., 2008). Furthermore, many difficulties associated with teaching and understanding molecular life science are connected to the abstract nature of concepts, which, in turn, are part of complex systems at several levels of organization (see below). Reasoning difficulties and alternative conceptions are major challenges for learners and teachers. In some cases, these difficulties are connected to the communicative tools of the domain. Both the domain-specific language and visualizations, aimed to facilitate communication, can constitute obstacles or introduce misinterpretations. Thus, research is required to provide further knowledge 
about factors that hinder or promote effective teaching and learning and to facilitate the development of effective new tools and strategies.

We claim that the challenges teachers and students face in the domain of molecular life science are multidimensional and unique. Here, we highlight several points to consider in molecular life science education, illustrated with examples, and suggest foci for future education research and teaching in the domain. The following aspects are discussed: 1) selection of molecular life science content, 2) conceptual understanding and reasoning difficulties, 3) domain specific-language, and 4) role and use of visualizations.

\section{CHALLENGES CONNECTED TO THE SELECTION OF CONTENT}

Molecular life science generates vast amounts of information rapidly. In addition, information technology has revolutionized our ability to acquire and use information from diverse sources such as databases of sequenced genomes, genes, proteins, protein structures, and expression profiles. Teachers cannot easily keep abreast of all the new information nor select appropriate aspects to disseminate, whereas learners-who lack training — cannot be expected to understand the information sufficiently to appraise it nor select aspects to learn. There is a need to identify and agree upon core content and to select key concepts (see below). An important aspect to consider is what constitutes a meaningful school education for students aiming to study science at the tertiary level, and also for students who will not further their formal education in science except school science (of which the latter group is in an overwhelming majority; Wright, 2005).

Molecular life science research is becoming increasingly interdisciplinary (integrating knowledge and methods from various fields), and multi- or crossdisciplinary (problem solving often involves teams including participants with widely varying competences), resulting in a steady erosion of traditional borders among chemistry, biology, physics, medicine, mathematics, and computer science (Huang, 2000). However, in schools in most countries, the domain is not treated in an integrated and problem-oriented manner, and different parts of molecular life science are taught separately. Some molecular life science content is taught in biology, some in chemistry, and some in natural or environmental science courses. According to Cheesman et al. (2007), very little has changed in life science courses since 1992, when the American Society for Biochemistry and Molecular Biology (ASBMB) developed an undergraduate curriculum in biochemistry and molecular biology (ASBMB, 2008). Teachers and students need knowledge in science and about science, i.e., to understand the way science works, how inquiries are pursued, and how knowledge is produced (Millar and Osborne, 1998).

The relationships among science, school science, and science in media and society are subject to ongoing reconsideration and revision. Driver et al. (1996) proposed that an understanding of three aspects should be considered: 1) core concepts, processes, and principles; 2) the scientific approach to enquiry; and 3) the interplay between science and society. The latter also includes the integration of ethical considerations into molecular life science teaching. In fact,
Sjøberg (1998) proposes that the main argument for the importance of science knowledge is cultural. However, knowledge in science is a prerequisite for reasoning meaningfully (Ekborg, 2003). All of these aspects are highly relevant to molecular life science, and education systems (primary, secondary, and tertiary) must be prepared to play a role in promoting and instilling this understanding of the subject and its implications.

Different stakeholders are taking steps to bridge the gap between the practice and teaching of molecular life science. Attempts to compile concept inventories for school and undergraduate life science education have been made. Scientific societies are trying to address the "content coverage" issue (Voet et al., 2003; American Society for Microbiology, 2006; ASBMB, 2008). Furthermore, Smith and colleagues (2008) recently designed a concept assessment tool to assess central concepts in genetics and diagnose misconceptions or preconceptions. The inventories above, and other studies (Yamamoto, 2003; Cheesman et al., 2007; Garvin-Doxas et al., 2007), stress the interdisciplinarity of the subject and the importance of combining elements of chemistry and biology with content from other subjects such as mathematics and physics. Others (Collins, 2002; National Research Council, 2003; Steitz, 2003; White, 2007) have all recommended an interdisciplinary approach to life science teaching that aims to develop students' critical reading skills and understanding of functions rather than facts. Recently, the International Union of Biochemistry and Molecular Biology (IUBMB) initiated an international project to scrutinize the core concepts in biochemistry and students' difficulties in learning biochemical concepts to create a biochemistry concept inventory (Howitt et al., 2008).

\section{Conclusions and Implications for Educational Research and Teaching}

A closer association between research developments and public understanding is required to avoid continual weakening of the connection between science education and science proper. The international attempts to agree on central concepts and principles are helping to create general guidelines for constructing curricula. One conclusion emerging from these inventories is that key concepts and central principles need to be identified during teaching rather than a plethora of details and that strategies to identify relationships and patterns have to be supported.

Furthermore, we suggest that the molecular life science community, in addition to identifying the concepts, needs to specify both the level of detail and depth of the concepts and processes that we intend our students to understand. For example, learning about photosynthesis might mean understanding that light is used to convert carbon dioxide into carbohydrates. At another level, it means a detailed understanding of how light is absorbed and excites chlorophyll, the consequent electron flow through photosystems II and I in the thylakoid membrane, the proton gradient thus generated, its involvement in the production of ATP and NADPH, and ultimately the fixation of carbon dioxide in the Calvin cycle in reaction sequences involving ATP and NADPH.

Another observation is that students' understanding of what constitutes the core content has received very little attention. The inventories generally take what scientists and 
teachers consider to be the core content as their starting points. It would be interesting to identify and explain possible discrepancies between the teachers' view and the students' understanding of what constitutes core content.

\section{CHALLENGES CONNECTED TO REASONING DIFFICULTIES}

An emerging viewpoint of cognition and learning suggests that the human body plays a central role in shaping the mind (Wilson, 2002). If so, the inability to directly experience the molecular world may explain many of the documented learning difficulties in molecular sciences. Students' conceptual and reasoning difficulties have been extensively reported in the science education research literature. Much of the published research on conceptual and reasoning difficulties in science are compiled in the Students' and Teachers' Conceptions Science Education (Duit, 2008; www.ipn. uni.-kiel.de/aktuell/stcse/stcse.html) and in the Conceptual and Reasoning Difficulties (www.card.unp.ac.za) databases. However, findings regarding challenges to learning molecular life science are relatively limited (Schönborn and Anderson, 2006). Difficulties have been reported regarding various aspects of genetics, cell structure and function, compartmentalization; macromolecular structure; cell metabolism (e.g., photosynthesis, respiration, coupled reactions, and inhibition of biochemical pathways); and signaling, as well as issues related to size and scale, biophysical concepts, and dynamic aspects such as diffusion and equilibrium. Each of these is described in more detail below.

\section{Difficulties in Connection to Genetics}

The most intensively studied field of molecular life science in educational research is student difficulties related to understanding genetics (Bahar et al., 1999; Banet and Ayuso, 2000; Knippels et al., 2005; Öztap et al., 2003). For example, common difficulties and alternative conceptions were identified in connection with germ cells and somatic cells, and the fact that different cell types in the human body contain identical genetic information (Banet and Ayuso, 2000; Lewis et al., 2000; Lewis and Wood-Robinson, 2000). Young children often believe that genes have a completely different function and even physical location compared with DNA; that plants are nonliving and do not reproduce sexually (Banet and Ayuso, 2000); and that inanimate objects, such as computers and fictional cartoon characters, have DNA (Venville et al., 2005). Several (mis)conceptions about transcription and translation have been identified as well, for example, that amino acids are produced by translation (Fisher, 1985). Other difficulties are associated with DNAstrand nomenclature and function (Gupthar and Anderson, 2003) and problems that students have connecting the structure and function of DNA and genes (Marbach-Ad, 2001). The use of the gene concept in education has been studied by Martins and Ogborn (1997), who concluded that there are two basic metaphorical models of the gene concept among students. In the first model, a gene is essentially seen as a particle with certain effects related to it, whereas in the second model, it is seen as a sequence of instructions. Interestingly, Gericke and Hagberg (2007) compared historical models and students' ideas about genetics and found extensive parallels between students' alternative understanding of genetics and the frameworks of different historical models.

\section{Difficulties Connected to Size and Cell Structure and Function}

Various investigations of what students of different ages know about the structure and functioning of cells suggest that most learners find these topics difficult to conceptualize (Marek, 1986; Dreyfus and Jungwirth, 1988; Westbrook and Marek, 1991; Tamir and Zohar, 1993; Flores et al., 2003). The establishment of relationships between cell structures and their functions is especially challenging for students who are not able to integrate them into the overall picture of the cell (Flores et al., 2003). One problem seems to be that the functional similarities between systems within the cell and body organs are often exaggerated. For example, nutrition within the cell is compared with the digestive system of the whole organism. Thus, students fail to connect biochemical processes with the functioning of the cell (Flores et al., 2003). Students also have difficulty conceptualizing the relative and absolute sizes of cells that, in turn, results in confusion between cells, atoms, and molecules and has been shown to interfere with students' development of a robust understanding of biological processes, such as diffusion (Westbrook and Marek, 1991).

\section{Difficulties Related to Cell Metabolism}

Students' misunderstanding of concepts associated with photosynthesis have been identified (Wood-Robinson; 1991, Lonergan, 2000; Ozay and Oztas, 2003; Marmaroti and Galanopoulou, 2006). Examples of the misunderstandings include plants acquire all their nutrients from the soil, plants only absorb green light, and photosynthesis only occurs during the night (Nerdel et al., 2002). Students also struggle to understand respiration (Cakir et al., 2002), glycolysis (Olivera et al., 2003), and coupling of reactions and inhibition of biochemical pathways (Schönborn and Anderson, 2003). Other reported examples are related to the structural and dynamic aspects of biomolecules, biophysical concepts, compartmentalization, and signaling (Roberts et al., 2005; Tang and Teng, 2005; Bivall Persson et al., 2006). Interestingly, very little research has explored students' understanding of the relationships between protein structure and function, which are fundamental to modern molecular life science.

\section{Difficulties Connected to Different Levels of Organization}

Bahar et al. (1999) have shown that a primary challenge of molecular life science learning is that the scientific content deals with phenomena at multiple levels of organization simultaneously. Perceivable phenomena (macro) are explained by molecular events that cannot be seen or touched (submicro) and that are communicated using symbolic representations. For example, to connect "gene" and "trait" with respect to eye color, students must connect visible traits with pigment molecules as well as the proteins involved in their synthesis and localization. These concepts must also be 
connected with symbolic ideas, such as capital "B," indicating a dominant allele and small " $\mathrm{b}$," indicating a recessive allele (Johnstone, 1991; Bahar et al., 1999). Similarly, macrolevel disease states can be explained as malfunctions of submicro-level genes or proteins that are represented by letter symbols that indicate changes in nucleotides or amino acids. With respect to photosynthesis, the growth of a tree is connected to the absorption of light quanta. Thus, a learner must understand how the excitation of electrons in organic molecules within the inner membrane of the chloroplast drives the osmotic pumping of protons and energy capture in chemical bonds, as well as how these processes are coupled to synthesis of cell components, cell division, cellulose production, and hence growth and development of all of the tree's tissues and organs.

\section{Difficulties with Interacting Complex Systems}

A large proportion of life science concepts relate to clusters of processes, which in turn relate to complex webs of biophysical, biochemical, and ecological phenomena. These concepts and processes have been referred to as emergent (Slotta and Chi, 2006) or complex (Jacobson, 2001). To understand emergent concepts, learners must be able to sift through complex information spaces, discriminate between important and unimportant information, and recognize critical patterns and relationships. They may need to translate across different frames of reference, consider the dynamics of models over time, and reason qualitatively about physical processes (White, 1993). They must be able to synthesize this information to build generic and "runnable mental models" (Larkin, 1983; Redish, 1993), which need to incorporate invisible factors and abstractions.

Jacobson (2001) has compared qualitative differences between experts' (scientists) and novices' (nonscience majors) descriptions of complex phenomena such as weather systems. He concluded that experts use ideas associated with complex systems theory, such as emergence, self-organization, and multiple agents, much more frequently than the novices. He argues that students' difficulties with particular biological concepts, such as evolution by natural selection, might stem from their inability to reason about complex systems. Further research is needed to characterize the nature of these difficulties.

\section{Conclusions and Implications for Educational Research and Teaching}

Students' understanding of concepts and reasoning difficulties have become major foci of research in science education. However, the difficulties in the field of molecular life science seem to differ somewhat in nature from conceptualization difficulties in other domains, such as chemistry and physics. For example, fragmentation of knowledge and difficulties in connecting and using knowledge may be more significant than alternative conceptions (Bell, 2001). We propose that research regarding students' conceptual understanding in molecular life science necessitates a different approach and focus. In accordance with Jacobson (2001), it is important to investigate how learners understand emerging scientific knowledge and the ideas related to complexity and complex systems of modern science. The choices of appropriate com- municative tools, such as language and visualizations, could prove to be critical for the transformation of molecular life science knowledge into teaching.

\section{CHALLENGES CONNECTED TO THE DOMAIN-SPECIFIC LANGUAGE}

The role of language in learning science has received increasing attention (Lemke, 1990; Sutton, 1995). According to Lemke, learning science is learning to participate in communicative practice of the science culture. The language of molecular life science is characterized by vivid use of metaphors, similes, anthropomorphisms, teleological expressions, scientific slang, abbreviations, acronyms, and mathematical relations, which are described in detail below.

\section{Metaphors and Intentional Reasoning}

Scientifically defined concepts that coincide with everyday language are a well-known source of difficulty in science education. In molecular life science, this difficulty may be less pronounced because there are no everyday meaning terms such as lipid, nucleotide, gene expression, and selfassembly. This lack of everyday referents can be advantageous, because there is little or no risk of misconceptions arising from everyday meanings. In contrast, the absence of "real-life" metaphors can make it difficult for people to envision abstract phenomena (Reif and Larkin, 1991; Fredriksen and White, 1992). Lakoff and Johnson (1980) propose that metaphors are an essential part of any domain, and spatial metaphors in particular are thought to enhance the meaningfulness of data and provide qualitative insight (Ericson, 1993).

Metaphors and analogies are commonly used in molecular life science to facilitate "visualization" of relevant concepts and processes. For example, mitochondria are described as power plants. Another strategy is to describe processes in terms of human characteristics (anthropomorphisms) or intentional (teleological) behavior, such as explaining the action of antibodies as attacking an invader. This strategy can cause problems for learners. Students often hold anthropomorphic views of cellular processes (Tamir and Zohar, 1993), such as the cell knowing what to take in and what to discard (Dreyfus and Jungwirth, 1988). In addition, expressions such as "... the signal peptide directs the protein to its target compartment..." are frequently used in teaching to describe the process whereby a translated polypeptide arrives at its appropriate location in the cell. However, the seemingly intention-laden term "directs" is used to describe the diffusion-controlled process of recognition between stochastically colliding molecules. Although teleological expressions and analogical reasoning may be important tools in the process of communicating and sense making (Kattmann, 2005), they may also be sources of misconception.

\section{The Jargon of Molecular Life Science}

Another characteristic of the language of molecular life science is the use of abbreviations and acronyms, which is pervasive in molecular life science. Molecular life sciences deal with phenomena that involve long, complex names, 
which are abbreviated for succinctness (e.g., Asn for asparagine, IgG for immunoglobulin, and SDS-PAGE for SDSpolyacrylamide gel electrophoresis). Proteins and genes are often identified, characterized, and named long before their functions are known. Their names are often based on their analytical properties rather than functions. For example, $p 53$ (protein 53) refers to a protein with an apparent molecular mass of $53 \mathrm{kDa}$ according to SDS-PAGE analysis, which was subsequently found to be a tumor suppressor and is now also known as tumor protein 53. Similarly, cytochrome P450 (P450) proteins were named according to their peak absorbance of visible light (at $450 \mathrm{~nm}$ ). They were then subsequently found to contain cytochrome $b_{5}$ and play primary roles in the biotransformation of various drugs and other xenobiotics. Hence, they are now sometimes called CYP, or CYP450 proteins. Although acronyms and jargon may facilitate communication among professionals in the field, it can create problems for learners.

\section{Concepts Changing Meaning}

Changes in meaning or multiple meanings of concepts are also obstacles for students' learning. Molecular life science continues to develop rapidly, and fundamental concepts change meaning or become more elaborate as new knowledge is generated. The ways in which a "gene" is defined are a prime example. When Wilhelm Johannsen coined the gene concept in 1909, he argued that it was free of any hypotheses about the physical and chemical nature of genes. Genes were seen as hypothetical inducers of characters and the gene concept was thus purely theoretical. A few years later, T. H. Morgan and colleagues gave the gene concept a material basis, based on positions in chromosomes. The classical gene concept emerged as an indivisible unit of transmission, recombination, mutation, and function. During the 1940s, the so-called neoclassical gene concept was introduced in which the gene (or cistron, the unit of genetic function) was seen as an entity divided into subunits, the so-called mutons (units of mutation) and recons (units of recombination). During the 1960s, the cistron was defined as the entity that produced a protein. Subsequently, we have found introns, overlapping genes, jumping genes, and repeated genes, thereby making it difficult, if not impossible, to establish a firm, comprehensive, and enduring definition (Portin, 1993). Recent findings in epigenetics also challenge the gene concept. Nevertheless, the gene concept has explanatory value in research and education, but its meaning is strongly dependent on context.

\section{Conclusions and Implications for Educational Research and Teaching}

Whether learners grasp the precise meaning that experts intend to convey when using a metaphorical or anthropomorphic expression can be difficult to determine. The relationship between the intended meaning and the language used is not always straightforward, and students' use of correct scientific terms does not necessarily parallel their depth of understanding. Rundgren et al. (2009) found that students can still express a scientific understanding of the translation process without actually using scientific terminology. Similarly, a study by Brown and Ryoo (2008) indicated that better learning occurred when students received an instructional sequence that was first presented in everyday language followed by traditional terminology to explain scientific content (in comparison with when the instructional sequence was reversed). We must ask ourselves whether we are assessing students' depth of understanding or their abilities to retrieve domain-specific terms, or both. The relationship between learning and the usage of a domain-specific language warrants further investigation. Another area that requires further research is how students' conceptions are influenced by the use of intentional expressions to explain random and stochastic processes.

Concepts with multiple meaning or that historically have changed their meaning should be treated with caution. Examples of these concepts can be used in teaching to draw attention to misconceptions, ambiguous meanings, and to explain ideas. For example, Gericke and Hagberg (2007) have shown that genetics teaching that explicitly shows how different models of gene function have been used historically, can clarify the gene concept for students.

\section{CHALLENGES CONNECTED TO VISUALIZATION}

\section{Visualizations and Molecular Life Science}

Visualizations play critical roles as conceptual tools in teaching and research, thereby transforming the way we think about molecular life science phenomena. Progress in molecular life science is connected to our ability to model abstract and complex content, and visualizations are used as sources of information and instruments of analysis, modeling, and communication (Kozma et al., 2000). Molecular life science researchers communicate and understand their science by using visualizations, and their success is connected to their ability to model the molecular world using abstract symbolic systems.

The importance of visualizations is evident in the molecular life science research literature. Textbooks are rich in illustrations and often include graphic supplements in the form of websites and educational software. For example, visualizations occupy $30-50 \%$ of the page space in standard biochemistry and molecular genetics textbooks (Tibell and Rundgren, unpublished data). These visualizations include chemical formulae and mechanisms, instrumental outputs, schemata, diagrams, illustrations, and photographs, as well as interactive models and animations provided as supplemental material.

Maddox (1998) predicted that molecular life science would increasingly adopt mathematical approaches to describe complex biological systems and make predictions regarding system-level phenomena. This is happening in several molecular life science subfields, for example, bioinformatics. Mathematical modeling increases the potential for using computers to describe complex molecular interactions numerically. These can, in turn, be used to generate simulations and create real-time animations and dynamic representations of molecular events, which can then be used to assess and understand fundamental concepts, systems, or processes and to test hypotheses and make predictions (Gilbert and Boulter, 1998). Computer-generated visualizations are also increasingly used in molecular life science education to promote 
more effective learning of visually and spatially complex topics.

Recent advances in virtual reality present opportunities for students to be immersed in complex, dynamic, and threedimensional structures and relationships via sensory aids such as haptics (Bivall Persson et al., 2006; Minogue and Gail Jones, 2006, 2008). Virtual environments introduce new modalities to learning and thus enable students to directly experience a phenomenon that then becomes more concrete and tangible. This may facilitate both teaching and scientific research by, for example, integrating more knowledge without causing cognitive overload.

The interpretation of visualizations is not unproblematic and depends on prior knowledge in the domain as well as familiarity with visualization, complexity of the visualization, and symbolism used in the visualization. Kozma (2003) found that experienced chemists move freely between different representations of a phenomenon, whereas students' interpretations are constrained by superficial features in the representations. Furthermore, Schönborn and Anderson (2006) demonstrated that several conceptual difficulties may be linked to the way the content is represented and the manner in which the symbolism is used. Students often see visualizations as realistic reproductions of the phenomena they depict (Harrison and Treagust, 2000). For example, students sometimes interpret diagrams as realistic depictions of the illustrated events, rather than as schematic representations. For example, du Plessis et al. (2002) traced students' difficulties in interpreting visualizations to misleading use of arrow symbolism in textbooks. Hull et al. (2002) demonstrated that the arrows between the metabolites in glycolysis were interpreted as a stream with a specific direction in the cytosolic solution rather than as a schematic representation of the order of reactions. Simple diagrams are often recommended. However, several studies indicate that the use of less stylized, less schematic, and more realistic images could be beneficial because the students take the stylized images as a realistic depiction of their structures (Menger et al., 1998).

There has been a long-standing debate in multimedia research on the educational value of animations. Several authors stress that animations can cause cognitive overload for learners (Tversky et al., 2002; Lowe, 2003) or give rise to new and resistant misconceptions (Tasker and Dalton, 2006). Other studies indicate that animations are superior for visualizing spatial aspects and dynamic processes (Williamson and Abraham, 1995; Pallant and Tinker, 2004; Marbach-Ad et al., 2008; Rundgren and Tibell, 2009). Furthermore, Wu et al. (2001) have shown that computer models can be beneficial in helping students to visualize how to transform a two-dimensional model into a three-dimensional (3-D) model. Salzman et al. (1999) found that students who struggled to understand concepts in protein structure and peptide bonding found multisensory cues, such as haptic and auditory feedback, more valuable than 3-D representations alone.

\section{Conclusions and Implications for Educational Research and Teaching}

Thinking about molecular life science requires the ability to envision and manipulate multidimensional information and to synthesize this information into working mental models that incorporate invisible and abstract ideas (Larkin, 1983; Redish, 1993; Gordin and Pea, 1995). We suggest that students must be familiar with these modes of communication to be successful academically. Instruction in molecular life science depends on the teachers' abilities to make its abstractions concrete and their abilities to help students build their "perceptualizing" skills. Visualizations can play a central role, but unreflective or idiosyncratic use of visual representations can cause confusion. It is important to consider the design of visualizations and their connection to learning goals, as well as the students' prior knowledge, when creating and using visualizations in education. For example, an animation on the Nobel Prize website depicts facilitated transport of water molecules through an aquaporin (http://nobelprize.org/chemistry/laureates/2003/animations. $\mathrm{html}$ ), effectively communicating the stochastic and dynamic properties of the process (Rundgren and Tibell, 2009). However, the absence of a depicted cell membrane puts high demands on the viewer to have prior knowledge in biochemistry to imagine the cell membrane.

More attention should be paid to learning how to read visualizations. It is important to stress that visualizations are representations or models, illustrating aspects of the represented phenomena. It is also important to relate the visualizations to phenomena and situations in the visible world and to discuss what aspects the visualizations represent, what is omitted, what they tell us, and what they do not tell. The ability to interpret visualizations is a skill (known as visual literacy), and fostering this skill is important for molecular life science learning (Schönborn and Anderson, 2006).

Most studies on students' interpretations of images and other visualizations have been conducted in physics education research (Pintó and Amteller, 2002), but relatively little is known about conditions that promote the effectiveness of illustrations, animations, and multimedia presentations of phenomena in molecular life science. More research is needed to understand the ways in which commonly used visualizations are perceived and to identify visualization features that are critical for learning.

\section{ADDITIONAL CHALLENGES AND THEIR IMPLICATIONS FOR TEACHING AND RESEARCH}

Molecular life science is unique in its prompting of ethical questions. Although other disciplines such as nuclear physics and sustainable development present ethical concerns, molecular life science deals with life itself. Thus, the discipline raises fundamental, philosophical, and ethical questions related to people's world views. Studies of student and public attitudes toward genetics and biotechnology indicate that they range from concern about or fear of the harmful consequences of biotechnology to intense curiosity and interest in the field and the potential it offers for improving human health and well being (Chen and Raffan, 1999; Jallinoja and Aro, 2000; Dawson and Schibeci, 2003; Chang and Chiu, 2008). When treated seriously during instruction, these questions can provide valuable perspectives, increase interest and engagement, and develop students' ability to 
engage in informed debate. Yet, scientists and teachers may feel unprepared to address ethical and philosophical issues in class, and may treat these inherently complex issues superficially or avoid them altogether. Molecular life science provides opportunities for collaboration between molecular life science and humanities professionals, such as experts in practical philosophy, ethics, and religious studies.

\section{CONCLUDING REMARKS}

Our aim in highlighting the challenging aspects of teaching and learning molecular life science is to establish a foundation for future education research and practice in the discipline. We are convinced that research in this domain can contribute to sound knowledge and understanding of the educational challenges and provide tools that can assist teachers and the educational system to meet these challenges.

In summary, core content, conceptual understanding, and communication of knowledge in molecular life science have been the foci of this essay. The search for key concepts and principles in this domain is ongoing. However, how to communicate to students what such core content comprises remains a critical issue. In fact, students' interpretation of what constitutes the core content of the domain is poorly investigated. Moreover, although research on conceptual difficulties in molecular life science is growing steadily, studies that focus on ways to overcome difficulties associated with depicting processes at different levels of organization are needed. We also suggest more research activity in the area of students' conceptual understanding of emerging concepts and complex processes. Nevertheless, central to teaching and learning is communication of the content of molecular life science: the language of molecular life science is distinct from the learners' everyday language. It is therefore crucial for our community to discover approaches that can help students acquire and utilize scientific language as their "everyday language." Another important communicative tool of molecular life science includes domain-specific visualizations. It follows that more knowledge is required about the best conditions for representational use as well as what representational features best aid understanding.

One fruitful way for facing the challenges illuminated in the essay would be to promote cross-domain collaborations. For example, cross-pollination among molecular life scientists, science education researchers, teachers, linguists, and psychologists (Garvin-Doxas, 2007; Howitt et al., 2008; Bivall Persson et al., 2006; Roberts et al., 2005; Rundgren et al., 2009) could pave the way toward improving educational practice in molecular life science.

\section{ACKNOWLEDGMENTS}

We thank Gunnar Höst, Bengt-Harald Jonsson, and Konrad Schönborn for valuable discussions and John Blackwell for reviewing the manuscript. This work was funded by the Swedish Research Council (grants 2003-4275 and 2006-2501), the Swedish National Graduate School of Research in Science and Technology Education, and the municipality of Norrköping, Sweden.

\section{REFERENCES}

American Society for Biochemistry and Molecular Biology (2008). Biochemistry/Molecular Biology Education: A Report to the Teagle Foundation. www.asbmb.org/Page.aspx?id=106\&linkidentifier $=$ id\&itemid=106. (accessed 14 January 2010).

American Society for Microbiology (2006). ASM's Curriculum Recommendations: Introductory Course in Microbiology. www.asm.org/index. php?option $=$ com_content\&view $=$ article\&id $=10051 \&$ Itemid $=9999$ (accessed 14 January 2010).

Bahar, M., Johnstone, A. H., and Hansell, M. H. (1999). Revisiting learning difficulties in biology. J. Biol. Educ. 33, 84-86.

Banet, E., and Ayuso, E. (2000). Teaching genetics at secondary school: a strategy for teaching about the location of inheritance information. Sci. Educ. 84, 313-351.

Bell, E. (2001). The future of education in the molecular life sciences. Nat. Rev. Mol. Cell. Biol. 2, 221-223.

Bivall Persson, P., Tibell, L., Cooper, M., and Ynnerman, A. (2006). Evaluating the effectiveness of Haptic Visualization in Biomolecular Education-Feeling Molecular Specificity in a Docking Task. Paper presented at the 12th IOSTE Conference, Penang, Malaysia.

Brown, B. A., and Ryoo, K. (2008). Teaching science as a language: a "content-first" approach to science teaching. J. Res. Sci. Teach. 45, $529-553$.

Cakir, Ö., Geban, Ö., and Yuruk, N. (2002). Effectiveness of conceptual change text-oriented instruction on students' understanding of cellular respiration concepts. Biochem. Mol. Biol. Educ. 30, 239-243.

Chang, S. N., and Chiu, M. H. (2008). Lakatos' scientific research programmes as a framework for analysing informal argumentation about socio-scientific issues. Int. J. Sci. Educ. 30, 1753-1773.

Cheesman, K., French, D., Cheesman, I., Swails, N., and Thomas, J. (2007). Is there any common curriculum for undergraduate biology majors in the 21st century? Bioscience 57, 516-522.

Chen, S. Y., and Raffan, J. (1999). Biotechnology: students knowledge and attitudes in the UK and Taiwan. J. Biol. Educ. 34, 17-23.

Collins, J. P. (2002). May you live in interesting times: using multidisciplinary and interdisciplinary programs to cope with change in life sciences. Bioscience 52, 75-83.

Dawson, V., and Schibeci, R. (2003). Western Australian high school students' attitudes towards biotechnology processes. J. Biol. Educ. $38,7-12$.

Dreyfus, A., and Jungwirth, E. (1988). The cell concept of 10th graders: curricular expectations and reality. Int. J. Sci. Educ. 10, 49-55.

Driver, R., Leach, J., Millar, R., and Scott, P. H. (1996). Young Peoples Images of Science, Buckingham, United Kingdom: Open University Press.

du Plessis, L., Anderson, T. R., and Grayson, D. J. (2002). Student difficulties with the use of arrow symbolism in biological diagrams. In: Proceedings of the IVth ERIDOB Conference, Toulouse, France.

Duit, R. (2008). Bibliography STCSE, Students' and Teachers' Conceptions and Science Education, Kiel, Germany: Institut für Pädagogik der Naturwissenschaften. www.ipn.uni.-kiel.de/aktuell/stcse/stcse.html (accessed 10 December 2009).

Ekborg, M. (2003). Naturvetenskaplig utbildning för hållbar utveckling?: en longitudinell studie av hur studenter på grundskollärarprogrammet utvecklar för miljöundervisning relevanta kunskaper i naturkunskap. Göteborg, Sweden: Göteborg Studies in Educational Sciences 188.

Ericson, T. (1993). Artificial realities as data visualization environments. In: Virtual Reality: Applications and Explorations, ed. A. Wexelblat, New York: Academic Press Professional, 1-22. 
Fisher, K. M. (1985). A misconception in biology: amino acids and translation. J. Res. Sci. Teach. 22, 53-62.

Flores, F., Tovar, M. E., and Gallegos, L. (2003). Representation of the cell and its processes in high school students: an integrated view. Int. J. Sci. Educ. 25, 269-286.

Fredriksen, J. R., and White, B. Y. (1992). Mental models and understanding: a problem for science education. In: New Directions in Educational Technology, ed. E. Scanlon and T. O'Shea, New York: Springer, 211-226.

Garvin-Doxas, K., Klymkowsky, M., and Elrod, S. (2007). Building, using, and maximizing the impact of concept inventories in the biological sciences: report on a National Science Foundation-sponsored Conference on the Construction of Concept Inventories in the Biological Sciences. CBE Life Sci. Educ. 6, 277-282.

Gericke, N. M., and Hagberg, M. (2007). Definition of historical models of gene function and their relation to students' understanding of genetics. Sci. Educ. 16, 849-881.

Gilbert, J. K., and Boulter, C. J. (1998). Learning science through models and modeling. In: International Handbook of Science Education, ed. B. J. Fraser and K. G. Tobin, Dordrecht, The Netherlands: Kluwer Academic Publishers, 53-66.

Gordin, D. N., and Pea, R. D. (1995). Prospects for scientific visualization as an educational technology. J. Learn. Sci. 4, 249-279.

Gupthar, A. S., and Anderson, T. R. (2003). Student difficulties associated with DNA-strand nomenclature and function. Paper presented at the Proceedings of the 11th Annual Meeting of the Southern African Association for Research in Mathematics, Science and Technology Education, Mbabane, Swaziland, 11-15 January, 2003, Vol. 1, 361-365. www.phy.uct.ac.za/saarmste/conferences.htm.

Harrison, A. G., and Treagust, D. F. (2000). A typology of school science models. Int. J. Sci. Educ. 22, 1011-1026.

Howitt, S., Anderson, T., Costa, M., Hamilton, S., and Wright, T. (2008). A concept inventory for molecular life sciences: how will it help your teaching practice? Australian Biochemist, 39, 14-17.

Huang, P. C. (2000). The integrative nature of biochemistry: challenges of biochemical education in the USA. Biol. Educ. 28, 64-70.

Hull, T. L., Anderson, T. R., and Grayson, D. J. (2002). Student difficulties with a diagram of the complement pathways in the immune system. In: C. Malcolm and C. Lubisi (eds.), Proceedings of the 10th Annual Meeting of the Southern African Association for Research in Mathematics, Science and Technology Education, University of Natal, Durban, 22-26 January, 2002, 129-135. www. phy.uct.ac.za/saarmste/conferences.htm.

Jacobson, M. J. (2001). Problem solving, cognition, and complex systems: differences between experts and novices. Complexity 6, $41-49$.

Jallinoja, P., and Aro, A. R. (2000). Does knowledge make a difference? The association between knowledge about genes and attitudes. J. Health Commun. 5, 29-39.

Johnstone, A. H. (1991). Why is science difficult to learn? Things are seldom what they seem. J. Comput. Assist. Learn. 7, 75-83.

Kattmann, U. (2005). Lernen mit anthropomorphen Vorstellungen? Ergebnisse von Untersuschungen zur Didaktischen Rekonstruktion in der Biologie. Z. Didaktik Naturwiss. 11, 165-174.

Knippels, M.-C.P.J., Waarlo, A. J., and Boersma, K. T. (2005). Design criteria for learning and teaching genetics. J. Biol. Educ. 39, 108-112.

Kozma, R. (2003). The material features of multiple representations and their cognitive and social affordances for science understanding. Learn. Instruct. 13, 205-226.

Kozma, R., Chin, E., Russell, J., and Marx, N. (2000). The roles of representations and tools in the chemistry laboratory and their implications for chemistry learning. J. Learn. Sci. 9, 105-143.
Lakoff, G., and Johnson, M. (1980). Metaphors We Live By, Chicago, IL: The University of Chicago Press.

Larkin, J. (1983). The role of problem representation in physics. In: Mental Models, ed. D. Gerner and A. Stevens, Hillsdale, NJ: Lawrence Erlbaum Associates, 75-98.

Lemke, J. L. (1990). Talking Science: Language, Learning and Values, Norwood, NJ: Ablex Publishing.

Lewis, J., Leach, J., and Wood-Robinson, C. (2000). What's in the cell? Young people's understanding of the genetic relationship between cells within an individual. J. Biol. Educ. 34, 129-132.

Lewis, J., and Wood-Robinson, C. (2000). Genes, chromosomes, cell division and inheritance-do students see any relationship? Int. J. Sci. Educ. 22, 177-195.

Lonergan, T. A. (2000). The photosynthetic dark reactions do not operate in the dark. Am. Biol. Teach. 62, 166-170.

Lowe, R. K. (2003). Animation and learning: selective processing of information in dynamic graphics. Learn. Instruct. 13, 157-176.

Maddox, J. (1998). What Remains To Be Discovered. Mapping the Secrets of the Universe, the Origins of Life, and the Future of the Human Race, New York: The Free Press.

Marbach-Ad, G. (2001). Attempting to break the code in student comprehension of genetic concepts. J. Biol. Educ. 35, 183-189.

Marbach-Ad, G., Rotbain, Y., and Stavy, R. (2008). Using computer animation and illustration activities to improve high school students' achievement in molecular genetics. J. Res. Sci. Teach. 45, 273-292.

Marek, E. A. (1986). They misunderstand, but they'll pass. Sci. Teach. 53, 32-35.

Marmaroti, P., and Galanopoulou, D. (2006). Pupils' understanding of photosynthesis: a questionnaire for the simultaneous assessment of all aspects. Int. J. Sci. Educ. 28, 283-403.

Martins, I., and Ogborn, J. (1997). Metaphorical reasoning about genetics. Int. J. Sci. Educ. 19, 47-63.

Menger, F. M., Zana, R., and Lindman, B. (1998). Portraying the structure of micelles. J. Chem. Educ. 75, 115

Millar, R., and Osborne, J. (ed.). (1998). Beyond 2000, Science Education for the Future. London, United Kingdom: Kings College, School of Education.

Minogue, J., and Gail Jones, M. (2006). Haptics in education: exploring an untapped sensory modality. Rev. Educ. Res. 76, 317-348.

Minogue, J., and Gail Jones, M. (2008). Measuring the impact of haptic feedback using the SOLO taxonomy. Int. J. Sci. Educ. 30, 1-20.

National Research Council (2003). Bio 2010, Transforming Undergraduate Education for Future Research Biologists. www.nap.edu/books/ 0309085357/html/ (accessed 10 December 2009).

Nerdel, C., Prechtl, H., and Bayrhuber, H. (2002). Interactive animations and understanding of biological processes: an empirical investigation on the effectiveness of computer-assisted learning environments in biology instruction. Paper presented at the Biology Education for the real world. Student-Teacher-Citizen. Proceedings of the IVth ERIDOB conference, Toulouse, France.

Olivera, G. A., Sousa, C. R., Da Poian, A. T., and Luz, M.R.M.P. (2003). Students' misconception about energy-yielding metabolism: glucose as the sole metabolic fuel. Adv. Physiol. Educ. 27, 97-101.

Ozay, E., and Oztas, H. (2003). Secondary students' interpretations of photosynthesis and plant nutrition. J. Biol. Educ. 37, 68-70.

Öztap, H., Özay, E., and Öztap, F. (2003). Teaching cell division to secondary school students: an investigation of difficulties experienced by Turkish teachers. J. Biol. Educ. 38, 13-15. 
Pallant, A., and Tinker, R. F. (2004). Reasoning with atomic-scale molecular dynamic models. J. Sci. Educ. Technol. 13, 51-66.

Pintó, R., and Amteller, J. (2002). Students' difficulties in reading images. Comparing results from four national research groups. Int. J. Sci. Educ. 24, 333-341.

Portin, P. (1993). The concept of the gene: short history and present status. Q. Rev. Biol. 68, 173-223.

Redish, E. (1993). The implications of cognitive studies for teaching physics. Am. J. Teach. Phys. 62, 796-803.

Reif, E., and Larkin, J. (1991). Cognition in scientific and everyday domains: comparison and learning implications. J. Res. Sci. Teach. $28,733-760$.

Roberts, J. R., Hagedorn, E., Dillenburg, P., Patrick, M., and Herman, T. (2005). Physical models enhance molecular three-dimensional literacy in an introductory biochemistry course. Biochem. Mol. Biol. Educ. 33, 105-110.

Rundgren, C.-J., Hirsch, R., and Tibell, L.A.E. (2009). Death of metaphors of life science?-a study of upper secondary and tertiary students' use of metaphors and help-words in their meaning-making of scientific content. Asia-Pacific Forum on Science Learning and Teaching 10, Article 3.

Rundgren, C.-J., and Tibell, L.A.E. (2009). Critical features of visualizations of transport through the cell membrane-an empirical study of upper secondary and tertiary students' meaning-making of a still image and an animation. Int. J. Sci. Math. Educ. doi:10.1007/ s10763-009-9171-1.

Salzman, M. C., Dede, C., Loftin, R. B., and Chem, J. (1999). A model for understanding how virtual reality aids complex conceptual learning. Presence 8, 293-316.

Schönborn, K. J., and Anderson, T. R. (2003). Biochemistry students' difficulties with chemical coupling. In: Proceedings of the 11th Annual Meeting of the Southern African Association for Research in Mathematics, Science and Technology Education, Mbabane, Swaziland, 11-15 January, 2003, 89-95. www.phy.uct.ac.za/saarmste/ conferences.htm.

Schönborn, K. J., and Anderson, T. R. (2006). The importance of visual literacy in the education of biochemists. Biochem. Mol. Biol. Educ. 34, 94-102.

Sjøberg, S. (1998). Naturfag som allmenndannelse: en kritisk fagdidaktikk, Oslo, Norway: Gyldendal.

Slotta, J. D., and Chi, M.T.H. (2006). Helping students understand challenging topics in science through ontology training. Cogn. Instr. 24, 261-289.

Smith, M. K., Wood, W. B., and Knight, J. K. (2008). The genetics concept assessment: a new concept inventory for gauging student understanding of genetics. CBE Life Sci. Educ. 7, 422-430. www. lifescied.org/cgi/content/full/7/4/422.
Steitz, J. A. (2003). Bio2010 - new challenges for biology educators. Cell Biol. Educ. 2, 87-91.

Sutton, C. (1995). Words, Science and Learning, Buckingham, United Kingdom: Open University Press.

Tamir, P., and Zohar, A. (1993). Anthropomorphism and teleology in reasoning about biological phenomena. Sci. Educ. 75, 57-67.

Tang, B. L., and Teng, F.Y.H. (2005). Concepts of protein sorting or targeting signals and membrane topology in undergraduate teaching. Biochem. Mol. Biol. Educ. 33, 188-193.

Tasker, R. F., and Dalton, R. M. (2006). Research into practice: visualisation of the molecular world using animations. Chem. Educ. Res. Pract. 7, 141-159.

Tversky, B., Morrison, J.-B., and Betrancourt, M. (2002). Animation: can it facilitate? Int. J. Hum. Comput. Stud. 57, 247-262.

Venville, G. J., Gribble, S. J., and Donovan, J. (2005). An exploration of young children's understanding of genetic concepts from ontological and epistemological perspectives. Sci. Educ. 89, 614-633.

Voet, J. G., Bell, E., Boyer, R., Boyle, J., O'Leary, M., and Zimmerman, J. K. (2003). Mini-Series: The ASBMB recommended biochemistry and molecular biology undergraduate curriculum and its implementation. Recommended curriculum for a program in biochemistry and molecular biology. Biochem. Mol. Biol. Educ. 31, 161-162.

Westbrook, S., and Marek, E. A. (1991). A cross-age study of student understanding of the concept of diffusion. J. Res. Sci. Teach. 23, 581-597.

White, B. (1993). Thinkertools: causal models, conceptual change, and scientific education. Cogn. Instr. 10, 1-100.

White, H. B. (2007). Do biology and chemistry educators talk to each other? Biochem. Mol. Biol. Educ. 35, 70.

Williamson, V. M., and Abraham, M. R. (1995). The effects of computer animation of the particulate mental models of college chemistry students. J. Res. Sci. Teach. 57, 247-262.

Wilson, M. (2002). Six views of embodied cognition. Psychonomic Bull. Rev. 9, 625-636.

Wood-Robinson, C. (1991). Young people's ideas about plants. Stud. Sci. Educ. 19, 119-135.

Wright, R. L. (2005). Points of view: content versus process: is this a fair choice? Cell Biol. Educ. 4, 189-196.

Wu, H. K., Krajcik, J. S., and Soloway, E. (2001). Promoting understanding of chemical representations: students' use of a visualization tool in the classroom. J. Res. Sci. Teach. 38, 5821-5842.

Yamamoto, K. (2003). BIO 2010, Transforming Undergraduate Education for Future Research Biologists. www.nap.edu/catalog.php?record id $=10497 \#$ toc (accessed 1 July 2008). 